\title{
EVALUASI KETIDAKPASTIAN PENGUKURAN MULTI-UNSUR DALAM MINERAL ZIRKON DENGAN METODE ANALISIS AKTIVASI NEUTRON
}

\section{THE EVALUATION OF UNCERTAINTY MEASUREMENT MULTI ELEMENTS IN THE ZIRCON MINERAL USING NEUTRON ACTIVATION ANALYSIS METHOD}

\author{
Sukirno*, Sri Murniasih, Rosidi, dan Samin \\ Pusat Teknologi Akselerator dan Proses Bahan - BATAN \\ Jl. Babarsari No.21 Kotak Pos 6101 ykbb Yogyakarta 55281 \\ *E-mail: sukirno@batan.go.id
}

Naskah diterima: 29 Oktober 2014, direvisi: 20 Februari 2015, disetujui: 18 Mei 2014

\begin{abstract}
ABSTRAK
Evaluasi analisis multi-unsur yang disertai perhitungan ketidakpastian unsur pada mineral zirkon yang berasal dari Sampit, Kalimantan Tengah dan Pulau Bangka telah dilakukan dengan metode Analisis Aktivasi Neutron (AAN). Tujuan penelitian ini adalah menentukan komposisi dan nilai ketidakpastian multi-unsur dalam mineral zirkon untuk memenuhi persyaratan ISO/IEC guide 17025-2008 yang telah diterapkan pada laboratorium AAN. Analisis menggunakan spektrometri gamma dengan detektor HPGe menghasilkan 21 unsur terdeteksi yang dibagi menjadi tiga kelompok (mayor, minor, dan kelumit). Evaluasi ketidakpastian pengukuran perlu dilakukan untuk meningkatkan kualitas dan tingkat kepercayaan hasil analisis. Hasil pengujian tidak akan bermakna tanpa disertai perhitungan ketidakpastian. Oleh karena itu, dilakukan evaluasi nilai perhitungan ketidakpastian pada hasil analisis semua unsur yang terkandung dalam mineral zirkon. Hasil analisis kuantitatif tertinggi adalah zirkonium ( $\mathrm{Zr}$ ) dengan konsentrasi $38,986 \%$ dan mempunyai nilai ketidakpastian $0,33 \%$ sehingga nilai konsentrasi nyata adalah $38,986 \pm 0,33 \%$, dalam oksida $\left(\mathrm{ZrO}_{2}\right)$ mempunyai konsentrasi $52,661 \pm 0,45 \%$. Unsur stibium (Sb) adalah unsur yang terdeteksi paling rendah dengan nilai konsentrasi dan ketidakpastian adalah $7 \pm 0,3 \mu \mathrm{g} / \mathrm{g}$ sedangkan dalam oksida $\left(\mathrm{Sb}_{2} \mathrm{O}_{3}\right)$ mempunyai konsentrasi $17 \pm 0,9 \mu \mathrm{g} / \mathrm{g}$. Komposisi oksida dan bahan kimia dalam mineral pasir zirkon yang lebih signifikan berasal dari Sampit dengan kandungan $\mathrm{ZrO}_{2}+\mathrm{HfO}_{2}(53-55 \%), \mathrm{F}_{2} \mathrm{O}_{3}$ (5-6\%), $\mathrm{TiO}_{2}$ (13-14\%), $\mathrm{Al}_{2} \mathrm{O}_{3}$ (1,5$2 \%)$ dan $\mathrm{SiO}_{2}$. Unsur $\mathrm{Si}\left(\mathrm{SiO}_{2}\right)$ tidak dapat ditentukan dengan metode AAN sebab tampang lintang Si sangat kecil.
\end{abstract}

Kata kunci: evaluasi unsur, ketidakpastian, komposisi oksida, AAN

\section{ABSTRACT}

The evaluation of multi-elements analysis has been carried out with calculation of element uncertainy in the zircon mineral from Sampit (Central Kalimantan) dan Bangka has been evaluated by the Neutron Activation Analysis (NAA) method. The purpose of this research is 
determination of composition and value of multi-elements uncertainty in the mineral of zircon to fulfil the requirements of ISO/IEC guide 17025-2008 that applied at NAA laboratory. The result of analysis using gamma spectrometry with a HPGe detector showed of 21 detected elements, divided into three groups (major, minor, and trace). Evaluation of uncertainty estimation should be done to increase quality and confidence rate of analysis results. The result of testing are not mean without calculation of uncertainty. Therefore, it was assessed the uncertainty measurement of all elements analysis in zircon mineral. The results of quantitative analysis is $\mathrm{Zr}$ with the highest concentration value of $38.986 \%$ and value of uncertainty is $0.331 \%$ so that value of real concentration is $38.986 \pm 0.331 \%$. In the form of oxide $\left(\mathrm{ZrO}_{2}\right)$ has concentration of $52.661 \pm 0.45 \%$. Sb element is the lowest element detected with value of concentration and uncertainty is $7 \pm 0,3 \mu \mathrm{g} / \mathrm{g}$. In the form of oxide $\left(\mathrm{Sb}_{2} \mathrm{O}_{3}\right)$ has concentration is $17 \pm 0.9 \mu \mathrm{g} / \mathrm{g}$. The oxide composition and the must important of chemicals in the zircon sand mineral more significant from Sampit which quantitative composition are $\mathrm{ZrO}_{2}+\mathrm{HfO}_{2}(53-$ $55 \%), \mathrm{F}_{2} \mathrm{O}_{3}$ (5-6\%), $\mathrm{TiO}_{2}$ (13-14\%), $\mathrm{Al}_{2} \mathrm{O}_{3}$ (1.5-2\%) and $\mathrm{SiO}_{2}$. Elements of $\mathrm{Si}\left(\mathrm{SiO}_{2}\right)$ can not be determined by NAA method because Si cross-sections is very small.

Keywords: evaluation of elements, uncertainty, composition of oxide, NAA

\section{PENDAHULUAN}

Zirkonium merupakan unsur yang cukup melimpah dan tersebar luas di Indonesia, khususnya di Sampit, Kalimantan Tengah dan Pulau Bangka. Mineral pasir zirkon merupakan mineral berat yang mempunyai densitas sekitar $2,9 \mathrm{~g} / \mathrm{cm}^{3}$ dan tidak pernah ditemukan di alam sebagai unsur tunggal, selalu terdapat bersama dengan hafnium yang memiliki sifat-sifat kimia yang hampir sama. Zirkonium dan hafnium keduanya dalam pasir zirkon memiliki rasio sekitar 50 banding $1^{[1]}$. Mineral yang paling penting dalam komposisi pasir zirkon adalah zirkonium silikat $\left(\mathrm{ZrSiO}_{4}\right)$ dan oksida bebas baddeleyete $\left(\mathrm{ZrO}_{2}\right)$. Kedua mineral ini dijumpai dalam bentuk senyawa dengan hafnium. Komposisi pasir zirkon adalah: $\mathrm{ZrO}_{2}+\mathrm{HfO}_{2}(65-67 \%)$, $\mathrm{SiO}_{2} \quad(32-36 \%), \quad \mathrm{F}_{2} \mathrm{O}_{3} \quad(0,05-0,2 \%), \quad \mathrm{TiO}_{2}$ $(0,10-0,25 \%), \quad \mathrm{Al}_{2} \mathrm{O}_{3} \quad(0,3-1 \%) \quad$ dan mengandung radionuklida alam, yaitu radionuklida ${ }^{238} \mathrm{U}, \quad{ }^{232} \mathrm{Th}, \quad$ serta anak luruhnya $^{[1,2]}$.
Mineral zirkon memiliki ketahanan pada suhu tinggi (titik leleh $2000-2500^{\circ} \mathrm{C}$ ), ketahanan korosi dan asam, konduktivitas panas tinggi, serta mempunyai sifat ekspansi termal yang rendah ${ }^{[3]}$. Mineral zirkon ini mempunyai refractive indices yang tinggi sehingga membuat zirkon sangat menarik untuk industri keramik. Zirkonium silikat merupakan salah satu bahan opasitas terkemuka yang digunakan oleh industri keramik seperti penyusunan glasir keramik dan ubin porselen. Manfaat lain dari mineral zirkon antara lain komponen elektronik yang memiliki penghantar ionik yang baik.

Dalam teknologi bahan bakar nuklir, penggunaan senyawa zirkonium memegang peranan cukup penting. Zirkonium mempunyai sifat-sifat nuklir dan nonnuklir yang sangat baik sehingga zirkonium dipakai sebagai bahan kelongsong elemen bahan nuklir (EBN), dengan tujuan agar tidak terjadi kontak langsung antara bahan bakar dengan pendingin sehingga hasil fisi tidak tersebar keluar $^{[4,5]}$. Kelebihan zirkonium antara lain 
mempunyai tampang lintang serapan neutron termal rendah, ketahanan korosi yang baik, serta mempunyai sifat mekanis yang relatif baik. Untuk dapat dipergunakan sebagai bahan starategis dalam industri nuklir, zirkonium diusahakan sudah bersih dari pengotornya, terlebih lagi terhadap unsur yang memiliki daya serap neutron tinggi, misalnya unsur hafnium $(\mathrm{Hf})^{[4]}$.

Analisis Aktivasi Neutron (AAN) adalah suatu metode analisis multi-unsur dalam suatu bahan sampel yang pengukurannya berdasarkan reaksi karakteristik radionuklida buatan dari unsur-unsur stabil. Prinsip dasar teknik AAN ini adalah apabila suatu bahan sampel yang terdiri dari berbagai unsur terjadi reaksi penangkapan neutron oleh inti unsurunsur tersebut. Bahan sampel diiradiasi dalam reaktor nuklir menggunakan neutron termal sehingga unsur-unsur yang terdapat dalam bahan sampel akan menjadi radioaktif dan mengeluarkan sinar gamma $^{[5]}$. Pembuatan aktivasi radiasi dipakai sebagai teknik untuk identifikasi kualitatif dan analisis kuantitatif.

Perhitungan ketidakpastian dilakukan dengan menyusun suatu model dari sistem pengukuran untuk mengetahui semua faktor yang dapat memberikan konstribusi kesalahan terhadap hasil akhir pengukuran. Faktorfaktor tersebut dievaluasi dan dikuantifikasi berdasarkan kategori sumber kesalahan, yaitu secara statistik untuk tipe A yang dievaluasi dari analisis rangkaian pengamatan dan untuk tipe B yang dievaluasi dengan cara selain dari analisis serangkaian pengamatan, berdasarkan informasi dari katalog, spesifikasi dari pabrik dan sebagainya berdasarkan informasi yang dapat dipercaya ${ }^{[6,7,8]}$. Kuantifikasi kesalahan tersebut dilakukan untuk mendapatkan ketidakpastian baku dari setiap komponen. Selanjutnya ketidakpastian baku digabungkan untuk mendapatkan ketidakpastian baku gabungan.

\section{Evaluasi ketidakpastian baku $(\mu)$ tipe A:}

Pengamatan berulang dapat dihitung kembali nilai rata-ratanya yang kemungkinan terjadi. Taksiran sebaran dari rata-rata populasi dapat dihitung dari simpangan baku (S) rata-rata eksperimental:

$$
\mu=\mathrm{S} / \sqrt{ } \mathrm{n} \text {. }
$$

\section{Evaluasi ketidakpastian baku $(\mu)$ tipe B:}

Nilai ketidakpastian baku sama dengan ketidakpastian bentangan dibagi dengan faktor cakupan yang diberikan dalam sertifikat. Bila tidak ada informasi faktor cakupan maka dapat diambil 2 (dua) dengan tingkat kepercayaan $95 \%{ }^{[8]}$, untuk distribusi normal persamaan (2) dan distribusi rektangular persamaan (3) dan untuk distribusi trangular persamaan (4).

$$
\begin{aligned}
& \mu(\mathrm{x})=\mathrm{S} / 2 \text {. } \\
& \mu(\mathrm{x})=\mathrm{S} / \sqrt{ } 3 \\
& \mu(\mathrm{x})=\mathrm{S} / \sqrt{6} \text {. }
\end{aligned}
$$

mempunyai suatu tingkat kepercayaan. Oleh karena itu, diperlukan pernyataan probabilitas bahwa nilai benarnya berada dalam rentang tersebut. Penetapan tingkat kepercayaan berdasar pada asumsi bahwa hasil pengukuran merupakan distribusi normal (Gauss). Dengan penetapan tingkat kepercayaan tersebut, diperoleh ketidakpastian diperluas ${ }^{[8]}$.

Tujuan penelitian ini adalah tersusunnya komposisi dan data konsentrasi unsur-unsur mayor, minor, dan kelumit dengan dilengkapi estimasi ketidakpastian unsur-unsur hasil analisis dalam pasir zirkon yang berasal dari daerah Sampit dan Pulau Bangka. Selain itu, juga untuk memenuhi persyaratan ISO/IEC guide 17025-2008 yang telah diterapkan pada laboratorium AAN dan untuk mendukung 
pembuatan kandidat bahan standar mineral zirkon "Certificate Reference Material (CRM) in house" PSTA-BATAN Yogyakarta.

\section{TATA KERJA}

\section{Alat dan bahan}

Alat yang digunakan meliputi reaktor nuklir Kartini, seperangkat spektometer gamma yang dilengkapi detektor HPGe dengan software Genie 2000, timbangan analitik terkalibrasi, ayakan Karl Colb 100 mesh, homogeneser, tumbukan tahan karat, vial polietilen, dan kelongsong iradiasi. Bahan standar sekunder dengan multi-unsur, bubuk selulosa, sampel mineral zirkon berasal dari daerah Sampit, Kalimantan Tengah dan Pulau Bangka. Sampel diambil dari beberapa lokasi, kemudian dicuplik menjadi satu sampel setiap daerah untuk dihaluskan dan dihomogenkan. Standar primer, yaitu Certificate Reference Material (CRM) pasir zirkon buatan PTAPBBATAN dan CRM $\mathrm{U}_{3} \mathrm{O}_{8}$ PATRON OIEA.

\section{Iradiasi menengah dan panjang}

Semua sampel (sampel mineral zirkon), standar sekunder, primer, dan blanko ditimbang sekitar $0,10 \mathrm{~g}$ dan dimasukkan ke dalam vial iradiasi, kemudian dimasukkan ke dalam kelongsong iradiasi. Kelongsong yang berisi sampel diberi nomor urut dan dikirim ke Bidang Reaktor PSTA. Iradiasi dilakukan dalam fasilitas sistem rabbit Lazy Susan, reaktor nuklir Kartini Yogyakarta. Waktu iradiasi dilakukan 2 kali 6 jam dengan fluks neutron sekisar $0,5 \cdot 10^{11} \mathrm{n} \cdot \mathrm{cm}^{-1} \cdot \mathrm{s}^{-1}$.

\section{Iradiasi pendek}

Iradiasi dilakukan dalam fasilitas sistem pneumatik dan dilakukan satu demi satu, dengan waktu iradiasi adalah 300 detik. Setelah cuplikan teraktivasi berada di teras reaktor selama 300 detik, langsung dikirim ke fasilitas sistem cacah. Waktu tunda dan pencacahan cuplikan masing-masing selama 300 detik. Sistem pengiriman cuplikan dilakukan dengan unit kendali sistem pemindahan pneumatik flexo rabbit transfer.

\section{Pencacahan metode AAN}

Pencacahan dilakukan setelah pendinginan 5 menit untuk radioaktif umur paruh pendek. Radioaktif umur paruh menengah setelah 4-5 hari kemudian dicacah dan untuk umur paruh panjang setelah 21 hari, kemudian dilakukan identifikasi kualitatif mengacu pada tenaga karakteristik setiap radionuklida unsur. Lama pencacahan sampel dan blanko dilakukan selama 900 detik dengan dua atau tiga kali pengulangan pencacahan setiap sampel.

Hasil analisis kuantitatif dari perhitungan pencacahan sampel kemudian dibandingkan dengan nilai cacah standar yang telah diketahui konsentrasinya, sering juga disebut secara komparatif berdasarkan persamaan (5). Semua perhitungan data yang ada dilakukan dengan bantuan aplikasi Excel.

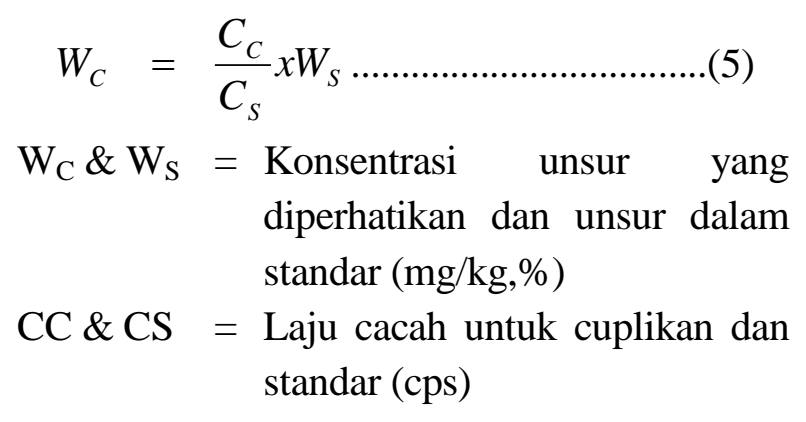

\section{Ketidakpastian}

Pengukuran ketidakpastian dilakukan untuk menjaga hasil analisis yang diperoleh dapat dikatakan valid. Dalam melakukan pengukuran ketidakpastian dari suatu metode perlu dilihat sumber yang dapat mengkontribusi ketidakpastian pada setiap tahapan kegiatan, mengkuantifikasi sumber ketidakpastian dari tiap-tiap komponen, menghitung ketidakpastian gabungan dari 
ketidakpastian baku tiap komponen, dan menghitung ketidakpastian yang diperluas. Perhitungan ketidakpastian gabungan $\left(\mu_{\mathrm{G}}\right)$ diperoleh berdasarkan persamaan (6)

Ketidakpastian gabungan $\left(\mu_{\mathrm{G}}\right)=\sqrt{\sum_{n}^{i} \mu i}$

$$
\begin{aligned}
& \mu_{\mathrm{G}}{ }^{2}=\mu_{\mathrm{A}}{ }^{2}+\mu_{\mathrm{B}}{ }^{2}+\mu_{\mathrm{C}}{ }^{2} \text { atau } \\
& \mu_{\mathrm{G}}=\left(\mu_{\mathrm{A}}{ }^{2}+\mu_{\mathrm{B}}{ }^{2}+\mu_{\mathrm{C}}{ }^{2}\right)^{0,5} \ldots . .
\end{aligned}
$$

Untuk mendapatkan probabilitas yang memadai sehingga nilai hasil uji berada dalam rentang yang diberikan oleh ketidakpastian maka dihitung ketidakpastian diperluas (U) dengan perkalian ketidakpastian baku gabungan dengan sebuah faktor pencakupan (k). Tingkat kepercayaan sekitar 95\% memberikan faktor pencakupan $2(\mathrm{k}=2)$ untuk ketidakpastian diperluas.

$$
\mathrm{U}=\mathrm{k} \cdot \mu_{\mathrm{C}} \text {. }
$$

\section{HASIL DAN PEMBAHASAN}

\section{Penentuan secara Kualitatif}

Penentuan unsur secara kualitatif dilakukan dengan mengetahui energi dari puncak-puncak karakteristik spektrum radioaktif hasil aktivasi neuton termal, kemudian mencocokkan dengan tabel isotop. Misal, untuk menentukan cobal (Co) maka hasil aktivasi neutron menjadi radioaktif adalah Co-60. Reaksi nuklir yang terjadi seperti persamaan di bawah ini:

Reaksi aktivasi neutron, seperti persamaan (8):

$$
\mathrm{Co}-59+\mathrm{n} \rightarrow \mathrm{Co}-60
$$

Pada reaksi aktivasi tersebut neutron $(n)$ ditembakkan ke Co-59 sehingga menghasikan radionuklida Co-60 yang bersifat radioaktif dengan energi karakteristik 1,173 $\mathrm{keV}$ (probabilitas 99,86\%) dan 1,332 $\mathrm{keV}$ (probabilitas 100,0\%) dan mempunyai umur paruh 5,272 tahun $^{[9]}$. Gambar 1 merupakan spektrum radionuklida umur paruh panjang untuk sampel mineral zirkon. Secara kualitatif dapat diketahui unsur-unsur yang diinginkan dengan melihat tenaga karakteristik dari radioaktif yang terjadi setelah melalui aktivasi neutron.

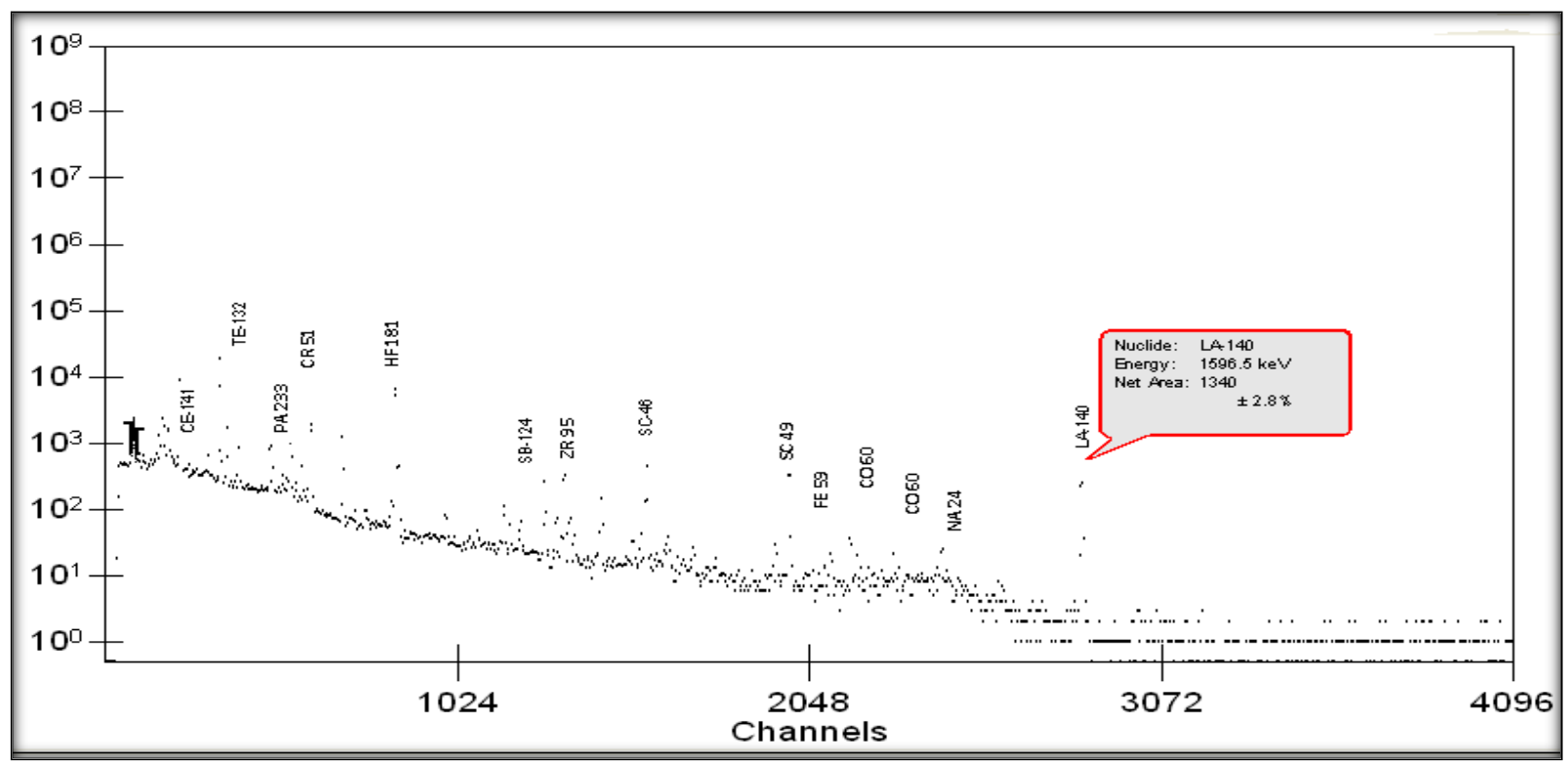

Gambar 1. Spektrum radionuklida umur panjang untuk sampel mineral zirkon ${ }^{[1]}$. 


\section{Analisis Aktivasi Neutron (AAN)}

Tabel 1 yang tersaji merupakan analisis multi-unsur secara kualitatif pada proses AAN dengan reaksi $(n, \gamma)$. Dasar kriteria untuk analisis multi-unsur dengan metode AAN adalah (1) fluks neutron dalam reaktor; (2) waktu iradiasi; (3) interval waktu tunda; (4) umur paruh dan energi sinar $\gamma$, dan (5) resolusi detektor HPGe dan dead time atau kemampuan detektor menerima radioaktivitas suatu sampel pasca iradiasi. Hasil analisis dipengaruhi oleh konsentrasi unsur dalam bahan matrik mineral zirkon dan tersedianya fasilitas pencacahan dan fasilitas radiasi. Rangkaian prosedur AAN biasanya terdiri dari iradiasi umur pendek, menengah, dan panjang dan ada tiga interval pencacahan seperti yang disajikan pada Tabel 1. Pada umumnya radionuklida hasil aktivasi mempunyai energi gamma karakteristik lebih dari pada satu, dapat dilihat pada tabel yang disusun oleh Erdtmann dan Soyka ${ }^{[9]}$.

\section{Penentuan secara kuantitatif}

Setelah diketahui beberapa jenis unsur logam yang terdapat dalam mineral zirkon secara kualitatif maka selanjutnya adalah penentuan secara kuantitatif. Analisis kuantitatif dilakukan dengan cara komparatif, yaitu membandingkan unsur-unsur dalam cuplikan dengan unsur-unsur yang ada dalam standar sekunder kemudian dikontrol dengan standar primer sebagai CRM yang komposisi kimianya teruji dan bersertifikat. Hasil identifikasi unsur-unsur dalam mineral zirkon yang berasal dari Sampit maupun Bangka kemudian dievaluasi secara kuantitatif sehingga dapat dibedakan menjadi tiga kelompok. Kelompok pertama adalah mayor unsur yang mempunyai konsentrasi di atas $1 \%$ $(1.000 .000 \mu \mathrm{g} / \mathrm{g})$, kelompok kedua adalah unsur minor dengan konsentrasi dari 1.000 $\mathrm{mg} / \mathrm{kg}(1.000 \mu \mathrm{g} / \mathrm{g})$ sampai dengan $1 \%$, dan kelompok ketiga adalah unsur kelumit di bawah $1.000 \mathrm{mg} / \mathrm{kg}^{[10]}$.

Tabel 1. Analisis multi-unsur secara kualitatif pada proses AAN dengan reaksi (n, $\gamma$ ).

\begin{tabular}{|c|c|c|c|c|c|}
\hline No & Unsur & Nuklida & Umur paruh & Energi, keV & Interval waktu tunda \\
\hline \multicolumn{6}{|c|}{ Radionuklida berumur pendek } \\
\hline 1 & $\mathrm{Ti}$ & Ti-51 & $5,79 \mathrm{~m}$ & 320 & \multirow{5}{*}{5 menit } \\
\hline 2 & $\mathrm{Mg}$ & Mg-27 & $9,46 \mathrm{~m}$ & 1014 & \\
\hline 3 & $\mathrm{~V}$ & V-52 & $3,75 \mathrm{~m}$ & 1434,2 & \\
\hline 4 & $\mathrm{Al}$ & $\mathrm{Al}-28$ & $2,32 \mathrm{~m}$ & 1779 & \\
\hline 5 & $\mathrm{Mn}$ & Mn-56 & 2,56 & 1811 & \\
\hline \multicolumn{6}{|c|}{ Radionuklida berumur menengah } \\
\hline 6 & $\mathrm{Na}$ & $\mathrm{Na}-24$ & $15,0 \mathrm{j}$ & 1369 & \multirow{3}{*}{$5-8$ hari } \\
\hline 7 & $\mathrm{U}$ & Np-239 & $56,3 \mathrm{j}$ & 228,278 & \\
\hline 8 & $\mathrm{La}$ & La-140 & $40,2 \mathrm{j}$ & 816,1597 & \\
\hline \multicolumn{6}{|c|}{ Radionuklida berumur menengah } \\
\hline 9 & $\mathrm{Ce}$ & Ce-141 & $32,5 \mathrm{~h}$ & 146 & \multirow{13}{*}{ 28-40 hari } \\
\hline 10 & Th & $\mathrm{Pa}-233$ & $27,0 \mathrm{~h}$ & 312 & \\
\hline 11 & $\mathrm{Cr}$ & Cr-51 & $27,8 \mathrm{~h}$ & 320 & \\
\hline 12 & Cs & Cs-134 & $2,05 \mathrm{t}$ & 796 & \\
\hline 13 & $\mathrm{Sb}$ & Sb-124 & $60,3 \mathrm{~h}$ & 564,1691 & \\
\hline 14 & $\mathrm{Hf}$ & Hf-181 & $42,5 \mathrm{~h}$ & 482 & \\
\hline 15 & $\mathrm{Zr}$ & Zr-95 & $65,5 \mathrm{~h}$ & 757 & \\
\hline 16 & $\mathrm{Nb}$ & $\mathrm{Nb}-95$ & $35 \mathrm{~h}$ & 765,8 & \\
\hline 17 & $\mathrm{Fe}$ & $\mathrm{Fe}-59$ & $45,6 \mathrm{~h}$ & 1099,1292 & \\
\hline 18 & $\mathrm{Sc}$ & Sc-46 & $83,9 \mathrm{~h}$ & 889,1121 & \\
\hline 19 & Co & Co-60 & $5,26 \mathrm{t}$ & 1173,1332 & \\
\hline 20 & $\mathrm{Yb}$ & Yb-175 & $4,21 \mathrm{~h}$ & 396 & \\
\hline 21 & Gd & Gd-153 & $236 \mathrm{~h}$ & 103,2 & \\
\hline
\end{tabular}

Catatan: $\mathrm{m}=$ menit, $\mathrm{j}=\mathrm{jam}, \mathrm{h}=$ hari, dan $\mathrm{t}=$ tahun 
Hasil analisis kandungan unsur mayor, minor, dan kelumit disajikan pada Tabel 2 . Pada Tabel 2 unsur logam mayor yang terdapat dalam mineral ada tiga unsur logam, yaitu $\mathrm{Zr}$, $\mathrm{Ti}$, dan $\mathrm{Fe}$ yang merupakan unsur logam dominan dalam mineral zirkon dari Sampit sedangkan yang berasal dari P. Bangka adalah $\mathrm{Zr}, \mathrm{Fe}$, dan $\mathrm{Ce}$. Untuk unsur $\mathrm{Ce}$ di mineral zirkon dari Sampit masuk kelompok unsur kelumit sedangkan unsur Ti di mineral zirkon dari P. Bangka masuk kelompok minor. Konsentrasi yang terbesar adalah unsur $\mathrm{Zr}$ dengan 38,986\% yang berasal dari Sampit. Secara ekonomis bila mineral zikon dari Sampit ini diproses menjadi zirkonia lebih menguntungkan daripada yang berasal dari $\mathrm{P}$. Bangka dengan kandungan $\mathrm{Zr}$ lebih kecil sekitar 23,07\%.

Hasil pengukuran unsur minor dalam mineral zirkon yang disajikan Tabel 2 ada 12 unsur minor. Unsur $\mathrm{Al}$ yang berasal dari mineral zirkon P. Bangka mempunyai konsentrasi yang tertinggi, yaitu 0,907\% dan unsur yang mempunyai konsentrasi terendah adalah unsur $\mathrm{Cr}$ dengan konsentrasi 0,110\% berasal dari mineral zirkon dari Sampit sedangkan unsur $\mathrm{Cr}$ dari daerah $\mathrm{P}$. Bangka di bawah batas deteksinya $(0,01 \mathrm{mg} / \mathrm{kg})$. Unsur Ti dari daerah Sampit masuk kelompok mayor dan unsur La serta Gd dari daerah Sampit dimasukkan dalam kelompok unsur kelumit.

Dalam kelompok unsur kelumit terdapat 12 unsur yang mempunyai konsentrasi terendah $7,069 \mathrm{mg} / \mathrm{kg}$, yaitu unsur $\mathrm{Sb}$ sampai dengan konsentrasi tertinggi adalah 840,36 $\mathrm{mg} / \mathrm{kg}$, yaitu unsur Yb. Khusus unsur Cs dalam mineral pasir zirkon yang berasal dari Bangka tidak terdeteksi, unsur $\mathrm{Ce}$ dan $\mathrm{La}$ masing-masing masuk kelompok mayor dan minor, dan unsur $\mathrm{V}$ dari Sampit masuk kelompok minor.

\section{Identifikasi Ketidakpastian}

Estimasi ketidakpastian pengukuran perlu dilakukan untuk meningkatkan kualitas dan tingkat kepercayaan hasil analisis serta untuk menetapkan ketelusuran hasil analisis terhadap satuan internasional. Faktor-faktor yang berpengaruh terhadap ketidakpastian dapat dilihat pada Gambar 2.

Tabel 2. Hasil rerata analisis kuantitatif unsur mayor, minor, dan kelumit dalam mineral zirkon dengan metode AAN.

\begin{tabular}{|c|c|c|c|c|c|c|c|c|}
\hline \multirow{2}{*}{ Unsur } & \multicolumn{2}{|c|}{ Mayor, (\%) } & \multirow{2}{*}{ Unsur } & \multicolumn{2}{|c|}{ Minor, $(\%)$} & \multirow{2}{*}{ Unsur } & \multicolumn{2}{|c|}{ Kelumit, (mg/kg) } \\
\hline & Sampit & Bangka & & Sampit & Bangka & & Sampit & Bangka \\
\hline $\mathrm{Fe}$ & 3,764 & 1,202 & $\mathrm{Al}$ & 0,549 & 0,9077 & $\mathrm{La}$ & 14,373 & $* *$ \\
\hline $\mathrm{Ti}$ & 10,076 & $* *$ & $\mathrm{Ti}$ & $*$ & 0,476 & Gd & 316,22 & $* *$ \\
\hline $\mathrm{Zr}$ & 38,986 & 23,07 & $\mathrm{Cr}$ & 0,110 & $\operatorname{ttd}$ & $\mathrm{U}$ & 400,82 & $* *$ \\
\hline $\mathrm{Ce}$ & $* * *$ & 2,847 & $\mathrm{Mg}$ & 0,111 & 0,341 & $\mathrm{Ce}$ & $*$ & 6,717 \\
\hline & & & Mn & 0,293 & 152,92 & $\mathrm{Mn}$ & $* *$ & 152,92 \\
\hline & & & Hf & 0,746 & 0,491 & $\mathrm{Sb}$ & 7,07 & 51,45 \\
\hline & & & $\mathrm{Nb}$ & 0,451 & 0,161 & Cs & 266,51 & $\operatorname{ttd}$ \\
\hline & & & Th & 0,128 & 0,559 & $\mathrm{Sc}$ & 70,694 & 68,544 \\
\hline & & & V & 0,136 & 20,11 & V & & 20,11 \\
\hline & & & $\mathrm{La}$ & $* * *$ & 0,115 & $\mathrm{Co}$ & 14,197 & 7,310 \\
\hline & & & $\mathrm{Gd}$ & $* * *$ & 0,189 & $\mathrm{Na}$ & 52,194 & 260,04 \\
\hline & & & $\mathrm{U}$ & $* * *$ & 0,128 & $\mathrm{Yb}$ & 411,28 & 840,36 \\
\hline
\end{tabular}

Catatan: * kelompok mayor, ** kelompok minor, $* * *$ kelompok kelumit, ttd: tidak terdeteksi 


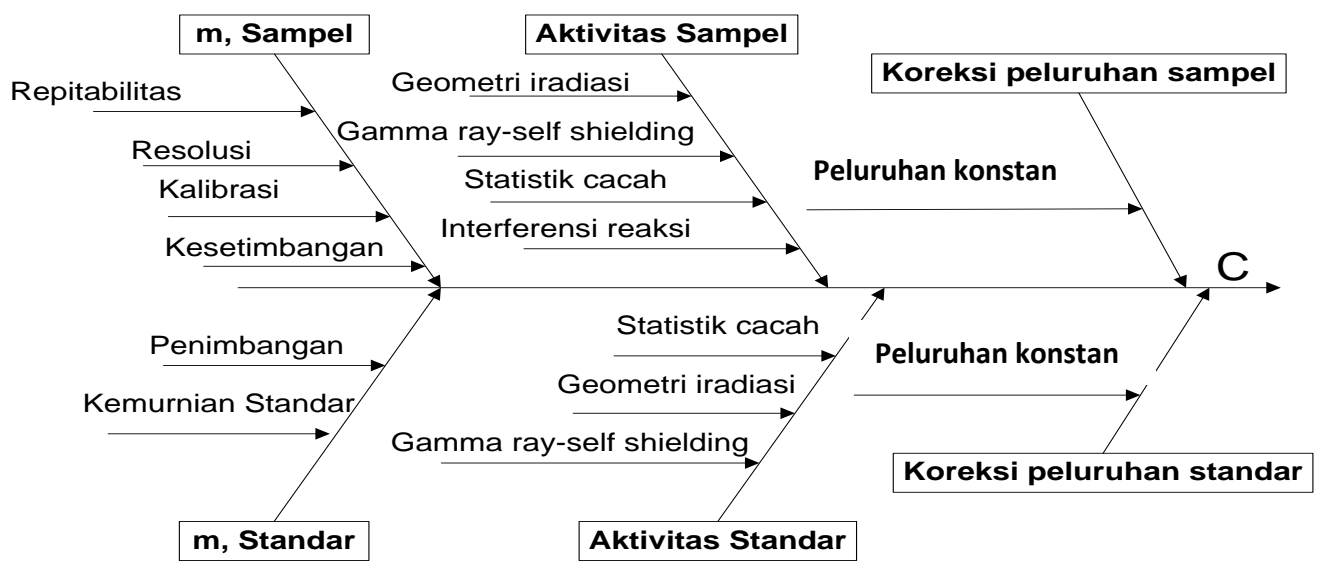

Gambar 2. Cause and effect diagram (fish-bone diagram) faktor-faktor yang berpengaruh pada ketidakpastian dengan metode $\mathrm{AAN}^{[12]}$.

Sumber ketidakpastian lainnya seperti perisai diri dan perbedaan hamburan, variasi spektrum neutron dalam ruangan dan waktu, gangguan reaksi nuklir, kerugian volatilisasi selama iradiasi dan durasi iradiasi diabaikan karena sampel, standar, CRM dan blanko bersama-sama diiradiasi dalam satu kelongsong yang sama dan dengan waktu yang sama. Sumber-sumber ketidakpastian dalam spektrometri gamma yang dibaikan adalah perbedaan geometri, gangguan sinar gamma, kerugian pulse-pileup, dan efek dead time ${ }^{[11]}$.

\section{Faktor yang berpengaruh pada ketidakpastian \\ Evaluasi langkah-langkah ketidakpastian yang dapat memberikan kontribusi nyata terdiri dari tiga kegiatan. Kegiatan yang dilakukan meliputi (1) preparasi cuplikan dan standar, (2) proses iradiasi, dan (3) pengukuran menggunakan spektrometer gamma $^{[12,13]}$. Rincian kegiatan yang berpengaruh terhadap ketidakpastian dapat dijelaskan sebagai berikut.}

\section{Preparasi sampel dan standar}

Faktor-faktor yang berkontribusi ketidakpastian preparasi cuplikan dan standar pada penimbangan, meliputi repitabilitas, resolusi, kalibrasi, kesetimbangan dari keempat nilai ketidakpastian tersebut ditentukan nilai ketidakpastian gabungan $\left(\mu_{\mathrm{gb}}\right)$ penimbangan sampel $0,26019 \mathrm{mg}^{[13]}$. Berat sampel dan standar masing-masing $100,00 \mathrm{mg}$ sehingga nilai relatif atau ketidakpastian gabungan penimbangan sampel $\left(\mu_{\mathrm{gsp}}\right)$ adalah $(0,26019 \mathrm{mg} / 100,00$ $\mathrm{mg}) \times 100 \%=0,26019 \%$.

Komponen ketidakpastian dari kemurnian standar yang berasal dari CRM adalah $\mathrm{Hf}=0,9063 \pm 0,0073 \%$ dan $\mathrm{Ti}=$ 1,6798 $\pm 0,0055 \%$. Ketidakpastian CRM untuk Hf dan Ti dan masing-masing adalah $\pm 0,0073$ dan $\pm 0,0055 \%$. Untuk distribusi normal menggunakan persamaan (2) sehingga ketidakpastian $\left(\mu_{\mathrm{CRM}}=\mathrm{S} / 2\right)$ unsur $\mathrm{HF}$ menjadi $0,0073 \% / 2=0,00365 \%$ dan unsur Ti $\left(\mu_{\mathrm{CRM}}\right)=0,0055 \% / 2=0,00275 \%$.

\section{Iradiasi}

Ketidakpastian baku karena perbedaan geometri iradiasi untuk radionuklida umur sedang dan panjang dengan metode komparatif, sampel dan standar dalam satu kelongsong sangat berdekatan sehingga diharapkan gradient fluks neutron minimum 
dan ketidakpastian dari komponen ini diabaikan. Untuk radionuklida umur pendek sistem pneumatik dihitung dari kalibrasi alat pencatat waktu otomatis $(1,000 \pm 0,03 \mathrm{~s})$ dengan asumsi distribusi probabilitas adalah rectangular maka ketidakpastian baku dari perbedaan geometri iradiasi $\left(\mu_{\mathrm{gg}}\right)$ sebesar $1,73.10^{-2}$ detik $^{[14]}$. Lama iradiasi 300 detik maka nilai relatif adalah $(0,0173$ detik $/ 300$ detik) $\mathrm{x} 100 \%=0,006 \%$.

\section{Faktor spektrometri sinar gamma}

Ketidakpastian dari komponen statistik cacah $\left(\mu_{\mathrm{s}}\right)$ diperoleh dari pengukuran hasil, diambil contoh radionuklida Hf-181 umur paruh panjang $\left(\mathrm{T}_{1 / 2}=45,2\right.$ hari $)$ yang mempunyai energi karakteristik 482,0 keV. Sampel mineral zirkon dari Bangka dan standar mempunyai hasil cacah 30260 dan 67464 dengan ketidakpastian masing-masing adalah 0,61 dan 0,40 sehingga nilai relatif ketidakpastian $=(30360 / 0,61) * 100=$ $0,00201 \%$ dan $0,0059 \%$. Untuk radionuklida umur pendek $\left(\mathrm{T}_{1 / 2}=5,79 \mathrm{mnt}\right)$ diwakili Ti-51 pada energi karakteristik 320,0 keV mempunyai hasil cacah berturut-turut 1519 dan 5097 dengan ketidakpastian masing-masing adalah 1,93 dan 8,66, nilai relatif ketidakpastian 0,12706\% dan 0,16990\%

Ketidakpastian dari komponen interferensi sinar gamma $\left(\mu_{\mathrm{i}}\right)$ yang mungkin terjadi adalah interferensi energi sinar gamma Ti-51 dan Cr51 yang memiliki energi yang sama yaitu 320,0 keV. Berhubung kedua radionuklida ini mempunyai $\mathrm{T}_{1 / 2}$ yang berbeda jauh dapat dilihat pada Tabel 1 maka pada iradiasi pendek (5 menit) diperkirakan Cr-51 belum terjadi. Sebaliknya pada iradiasi panjang ( 2 x 6 jam) dengan waktu pendinginan beberapa menit saja $\mathrm{T}_{1 / 2}$ dari Ti-51 sudah habis sehingga kontribusi ketidakpastian dari interferensi sinar gamma ini dapat diabaikan.
Ketidakpastian gamma ray self shielding memiliki kontribusi signifikan hanya untuk pengukuran radionuklida yang mempunyai energi $<100 \mathrm{keV}^{[15]}$. Pada penelitian ini yang yang terendah adalah 103,2 $\mathrm{keV}$ untuk radionuklida Gd-153 sehingga ketidakpastian dari gamma ray self shielding dapat diabaikan.

Kontribusi ketidakpastian peluruhan konstan $\left(\mu_{\mathrm{d}}\right)$ bergantung kepada ketidakpastian umur paruh dari radionuklida sedangkan untuk umur panjang dapat dibaikan ${ }^{[11,12]}$. Ketidakpastian umur paruh $\left(\mathrm{T}_{1 / 2}\right)$ diambil dari tabel Nuclear Wallet Cards yang disusun oleh TULI ${ }^{[15]}$. Ketidakpastian $\left(\mathrm{T}_{1 / 2}\right)$ kemudian dirubah menjadi ketidakpastian koreksi peluruhan $\left(\mu_{\mathrm{D}}\right)^{[12]}$ dimana untuk Ti-51 mempunyai $\left(\mathrm{T}_{1 / 2}\right) \quad 5,79$ menit dengan ketidakpastian $\pm 0,001^{[15]}$ menit atau ketidakpastian koreksi peluruhan relatif $\left(\mu_{\mathrm{D}}\right)$ menjadi $(5,79 / 0,001) \times 100 \%=0,0173 \%$.

Evaluasi nilai ketidakpastian gabungan $\left(\mu_{\mathrm{G}}\right)$ yang diperoleh dari komponenkomponen yang memberikan kontribusi nyata terhadap ketidakpastian digabungkan dengan menggunakan metode komparatif. Pada Tabel 3 untuk unsur yang mempunyai umur paruh panjang yang diwakili unsur Hf ada 5 (lima) komponen ketidakpastian sedangkan umur paruh pendek yang diwakili unsur $\mathrm{Ti}$ ada 8 (delapan) komponen ketidakpastian. Dari rangkuman komponen ketidakpastian dapat ditentukan ketidakpastian gabungan $\left(\mu_{\mathrm{G}}\right)$ dengan menggunakan persamaan (6). Hasil perhitungan nilai ketidakpastian gabungan unsur $\mathrm{Hf}\left(\mu_{\mathrm{G}-\mathrm{Hf}}\right)=0,3680 \%$ dan ketidakpastian gabungan unsur $\mathrm{Ti}\left(\mu_{\mathrm{G}-\mathrm{Ti}}\right)=$ $0,4255 \%$. Nilai ketidakpastian tersebut diakibatkan adanya kesalahan acak dan kesalahan sistemik. Kesalahan acak, yaitu kesalahan tanpa disengaja, bervariasi dari satu uji ke uji berikutnya. Kesalahan ini sulit dihindari karena disebabkan fluktasi yang tidak diduga-duga ${ }^{[16]}$. Kesalahan sistemik dapat 
disebabkan kesalahan kalibrasi, kesalahan komponen alat, gesekan, dan ruang bekerja.

Ketidakpastian konsentrasi unsur Hf dan Ti gabungan diperluas pada Tabel 4 menghasilkan ketidakpastian diperluas untuk unsur Hf dengan nilai $0,0036 \%$ dan unsur Ti mempunyai nilai $0,004 \%$ sehingga hasil konsentrasi analisis Hf dapat ditulis dengan nilai $0,491 \%$ pada Tabel 2 disertai nilai ketidakpastian dapat ditulis menjadi $0,491 \pm 0,0036 \%$. Hal ini dapat diartikan konsentrasi unsur hafnium (Hf) dalam mineral zirkon yang berasal dari Bangka nilai benar terletak di antara $(0,49-0,0036) \%=0,4874 \%$ sampai dengan $(0,491+0,0036) \%=0,4946 \%$. Untuk unsur titanium (Ti) konsentrasi sebenarnya adalah $0,476 \pm 0,004 \%$, terletak dengan nilai benar konsentrasi unsur Ti antara $0,472 \%$ sampai dengan $0,480 \%$. Dengan cara yang sama hasil uji analisis komposisi multiunsur pada Tabel 2, dapat ditentukan ketidakpastian masing-masing unsur. Hasil hitung ketidakpastian disajikan pada Tabel 5.
Pada Tabel 5 disajikan hasil pengukuran konsentrasi unsur dan konsentrasi dalam bentuk oksida dengan nilai ketidakpastian. Semua unsur dalam bentuk mayor, minor, dan kelumit disajikan dalam satu tabel dengan satuan unsur dan bentuk oksida dalam\%. Nilai suatu hasil pengujian unsur dalam cuplikan tidak akan bermakna tanpa disertai dengan perhitungan nilai ketidakpastian. Demikian juga pada hasil uji konsentrasi unsur dalam mineral zirkon yang disertakan nilai ketidakpastiannya setiap unsur. Nilai ketidakpastian cukup baik apabila nilai ketidakpastian suatu unsur dibagi atau dibandingkan dengan nilai uji konsentrasi unsur, disebut deviasi relatif dalam nilai prosentasi dibawah $10 \%^{[13]}$. Diambil contoh $\mathrm{Fe}_{2} \mathrm{O}_{3}$ dari Tabel 5 yang mempunyai konsentrasi nyata $3,437 \pm 0,228 \%$ sehingga deviasi relatif dari $\mathrm{Fe}_{2} \mathrm{O}_{3}$ adalah $(0,228 / 3,437) * 100 \%=6,63 \%$.

Tabel 3. Ketidakpastian baku relatif (\%) perhitungan pada analisis $\mathrm{Hf}$ dan Ti.

\begin{tabular}{|c|c|c|c|}
\hline \multirow[t]{2}{*}{ No } & \multirow[t]{2}{*}{ Komponen ketidakpastian } & \multicolumn{2}{|c|}{ Ketidakpastian baku relatif $(\%)$} \\
\hline & & Hf & $\mathrm{Ti}$ \\
\hline 1 & Preparasi sampel $\left(\mu_{\mathrm{g}-\mathrm{sp}}\right)$ & 0,26019 & 0,26019 \\
\hline 2 & Preparasi standar $\left(\mu_{\mathrm{g}-\mathrm{std}}\right)$ & 0,26019 & 0,26019 \\
\hline 3 & Kemurnian standar $\left(\mu_{\mathrm{CRM}}\right)$ & 0,00365 & 0,00275 \\
\hline 4 & Geometri iradiasi sampel $\left(\mu_{\mathrm{gs}}\right)$ & diabaikan & 0,006 \\
\hline 5 & Geometri iradiasi standar $\left(\mu_{\mathrm{gst}}\right)$ & diabaikan & 0,006 \\
\hline 6 & Statistik cacah sampel $\left(\mu_{\mathrm{s}}\right)$ & 0,00202 & 0,12707 \\
\hline 7 & Statistik cacah standar $\left(\mu_{\mathrm{st}}\right)$ & 0,00059 & 0,16990 \\
\hline \multirow[t]{5}{*}{8} & Peluruhan konstan $\left(\mu_{\mathrm{d}}\right)$ & diabaikan & 0,0173 \\
\hline & \multicolumn{3}{|l|}{ Ketidakpastian gabungan $\left(\mu_{\mathrm{G}}\right)$} \\
\hline & \multicolumn{3}{|c|}{$\mu_{\mathrm{G}}=\left[\left(\mu_{\mathrm{g}-\mathrm{sp}}\right)^{2}+\left(\mu_{\mathrm{g}-\mathrm{std}}\right)^{2}+\left(\mu_{\mathrm{CRM}}\right)^{2}+\left(\mu_{\mathrm{gs}}\right)^{2}+\left(\mu_{\mathrm{gst}}\right)^{2}+\left(\mu_{\mathrm{s}}\right)^{2}+\left(\mu_{\mathrm{st}}\right)^{2}+\left(\mu_{\mathrm{d}}\right)^{2}\right]^{0,5}$} \\
\hline & \multicolumn{3}{|c|}{$\begin{aligned} \mu_{\mathrm{G}(\mathrm{Ti})} & =\left[(0,26019)^{2}+(0,26019)^{2}+(0,00275)^{2}+(0,006)^{2}+(0,006)^{2}+(0,12707)^{2}+(0,16990)^{2}+(0,0173)^{2}\right]^{0,5} \\
& =0,4255 \%\end{aligned}$} \\
\hline & \multicolumn{3}{|c|}{ Ketidakpastian gabungan $\left(\mu_{\mathrm{G}(\mathrm{Hf})}\right)=0,3680 \%$} \\
\hline
\end{tabular}

Tabel 4. Hasil nilai hitung ketidakpastian unsur Hf dan Ti secara komporatif

\begin{tabular}{lcc}
\hline Kuantitas & Nilai, unsur Hf & Nilai, unsur Ti \\
\hline Faktor cakupan, tingkat kepercayaan 95\% & 2 & 2 \\
Ketidakpastian diperluas, persamaan $(7)$ & $0,3680 \% * 2=0,736$ & $0,4255 \% * 2=0,851$ \\
Konsentrasi unsur (dari Tabel 2), $\mathrm{W}_{\mathrm{C}}$ & 0,491 & 0,476 \\
Ketidakpastian komparatif $\left(\mu_{\mathrm{K}}\right)$ & $0,491 * 0,736 / 100=0,0036$ & $0,476 * 0,851 / 100=0,004$ \\
Konsentrasi unsur dalam contoh uji & $0,491 \pm 0,0036$ & $0,476 \pm 0,004$ \\
\hline
\end{tabular}


Tabel 5. Hasil pengukuran unsur dan dalam bentuk oksida dengan nilai ketidakpastian

\begin{tabular}{|c|c|c|c|c|c|c|}
\hline \multirow[t]{2}{*}{ No } & \multirow[t]{2}{*}{ Unsur } & \multicolumn{2}{|c|}{ Konsentrasi unsur\% } & \multirow[t]{2}{*}{ Oksida } & \multicolumn{2}{|c|}{ Konsentrasi bentuk oksida, $\%$} \\
\hline & & Sampit & Bangka & & Sampit & Bangka \\
\hline 1 & $\mathrm{Zr}$ & $38,986 \pm 0,33$ & $23,07 \pm 0,38$ & $\mathrm{ZrO}_{2}$ & $52,661 \pm 0,45$ & $31,163 \pm 0,51$ \\
\hline 2 & $\mathrm{Ti}$ & $10,076 \pm 0,05$ & $0,476 \pm 0,004$ & $\mathrm{TiO}_{2}$ & $16,807 \pm 0,083$ & $0,794 \pm 0,007$ \\
\hline 3 & $\mathrm{Fe}$ & $3,764 \pm 0,32$ & $1,202 \pm 0,08$ & $\mathrm{Fe}_{2} \mathrm{O}_{3}$ & $10,763 \pm 0,915$ & $3,437 \pm 0,228$ \\
\hline 4 & $\mathrm{Ce}$ & $0,0007 \pm 4 \mathrm{E}-5$ & $2,847 \pm 0,02$ & $\mathrm{CeO}_{2}$ & $0,0008 \pm 4 \mathrm{E}-5$ & $3,497 \pm 0,02$ \\
\hline 5 & $\mathrm{Al}$ & $0,549 \pm 0,006$ & $0,9077 \pm 0,048$ & $\mathrm{Al}_{2} \mathrm{O}_{3}$ & $2,074 \pm 0,023$ & $3,429 \pm 0,18$ \\
\hline 6 & $\mathrm{Cr}$ & $0,110 \pm 0,007$ & $\operatorname{ttd}$ & $\mathrm{Cr}_{2} \mathrm{O}_{3}$ & $0,3215 \pm 0,02$ & $\operatorname{ttd}$ \\
\hline 7 & $\mathrm{Mg}$ & $0,111 \pm 0,008$ & $0,341 \pm 0,028$ & $\mathrm{MgO}$ & $0,182 \pm 0,014$ & $0,565 \pm 0,046$ \\
\hline 8 & $\mathrm{Mn}$ & $0,293 \pm 0,002$ & $0,015 \pm 0,001$ & $\mathrm{MnO}_{2}$ & $0,463 \pm 0,003$ & $0,024 \pm 0,002$ \\
\hline 9 & Hf & $0,746 \pm 0,083$ & $0,491 \pm 0,004$ & $\mathrm{HfO}_{2}$ & $0,879 \pm 0,098$ & $0,579 \pm 0,011$ \\
\hline 10 & $\mathrm{Nb}$ & $0,451 \pm 0,019$ & $0,161 \pm 0,004$ & $\mathrm{NbO}_{2}$ & $0,606 \pm 0,025$ & $0,216 \pm 0,005$ \\
\hline 11 & Th & $0,128 \pm 0,003$ & $0,559 \pm 0,001$ & $\mathrm{ThO}_{2}$ & $0,146 \pm 0,004$ & $0,636 \pm 0,001$ \\
\hline 12 & V & $0,136 \pm 5 E-4$ & $0,020 \pm 2 \mathrm{E}-4$ & $\mathrm{~V}_{2} \mathrm{O}_{5}$ & $0,485 \pm 0,002$ & $0,071 \pm 9 \mathrm{E}-4$ \\
\hline 13 & $\mathrm{La}$ & $0,014 \pm 0,001$ & $0,115 \pm 0,006$ & $\mathrm{La}_{2} \mathrm{O}_{3}$ & $0,033 \pm 0,003$ & $0,269 \pm 0,014$ \\
\hline 14 & $\mathrm{Gd}$ & $0,032 \pm 0,002$ & $0,189 \pm 0,016$ & $\mathrm{Gd}_{2} \mathrm{O}_{3}$ & $0,073 \pm 0,006$ & $0,436 \pm 0,037$ \\
\hline 15 & $\mathrm{U}$ & $0,040 \pm 7 \mathrm{E}-4$ & $0,128 \pm 0,06$ & $\mathrm{U}_{3} \mathrm{O}_{8}$ & $0,142 \pm 0,003$ & $0,453 \pm 0,21$ \\
\hline 16 & $\mathrm{Sb}$ & $0,0007 \pm 3 E-5$ & $0,005 \pm 3 E-4$ & $\mathrm{Sb}_{2} \mathrm{O}_{3}$ & $0,0017 \pm 9 \mathrm{E}-5$ & $0,012 \pm 7 \mathrm{E}-4$ \\
\hline 17 & Cs & $0,027 \pm 0,001$ & $\mathrm{ttd}$ & $\mathrm{Cs}_{2} \mathrm{O}$ & $0,056 \pm 0,003$ & $\mathrm{ttd}$ \\
\hline 18 & $\mathrm{Sc}$ & $0,071 \pm 0,003$ & $0,068 \pm 0,003$ & $\mathrm{Sc}_{2} \mathrm{O}_{3}$ & $0,022 \pm 0,001$ & $0,021 \pm 0,001$ \\
\hline 19 & $\mathrm{Co}$ & $0,014 \pm 0,001$ & $0,0007 \pm 6 \mathrm{E}-5$ & $\mathrm{Co}_{2} \mathrm{O}$ & $0,032 \pm 0,002$ & $0,016 \pm 0,001$ \\
\hline 20 & $\mathrm{Na}$ & $0,052 \pm 0,004$ & $0,026 \pm 0,002$ & $\mathrm{Na}_{2} \mathrm{O}$ & $0,014 \pm 0,001$ & $0,070 \pm 0,006$ \\
\hline 9 & $\mathrm{Yb}$ & $0,041 \pm 0,002$ & $0,084 \pm 0,005$ & $\mathrm{Yb}_{2} \mathrm{O}_{3}$ & $0,094 \pm 0,006$ & $0,191 \pm 0,013$ \\
\hline
\end{tabular}

Ttd $=$ tidak terdeteksi

\section{KESIMPULAN}

Hasil analisis unsur-unsur dalam mineral zirkon dari daerah Sampit, Kalimantan Tengah dan Bangka teridentifikasi 21 unsur yang terdeteksi menggunakan spektrometri gamma dengan detektor HPGe. Unsur-unsur yang terkandung dalam mineral zirkon tersebut dibagi menjadi tiga kelompok. Kelompok pertama adalah unsur mayor $(\mathrm{Zr}, \mathrm{Ti}, \mathrm{Fe}$, dan $\mathrm{Ce}$ ), kelompok kedua adalah unsur minor (Al, $\mathrm{Cr}, \mathrm{Mg}, \mathrm{Hf}, \mathrm{Nb}, \mathrm{Th}, \mathrm{V}, \mathrm{Gd}$, dan U) dan kelompok ketiga merupakan unsur kelumit ( $\mathrm{Sb}$, Cs, Sc, Co, Na, Ce, La, Yb, Gd, V, dan Mn).

Nilai ketidakpastian sangat bermakna dalam analisis pengujian unsur dalam mineral zirkon, kelompok mayor dan minor diwakili unsur $\mathrm{Zr}$ dengan konsentrasi tertinggi dengan konsentrasi rerata 38,986\%, dan kelompok kelumit diwakili unsur $\mathrm{Sb}$ dengan konsentrasi terendah $0,0007 \%$ atau $7 \mu \mathrm{g} / \mathrm{g}$, yang mempunyai nilai ketidakpastian masingmasing adalah $0,33 \%$ dan $0,00003 \%$ atau 0,3 $\mu \mathrm{g} / \mathrm{g}$ sehingga konsentrasi nyata $\mathrm{Zr}$ menjadi
$38,986 \pm 0,33 \%$ dan $\mathrm{Sb}$ mempunyai konsentrasi nyata adalah $7 \pm 0,3 \mu \mathrm{g} / \mathrm{g}$. Hal ini dapat diartikan nilai benar konsentrasi unsur $\mathrm{Zr}$ terletak diantara $38,656 \%$ sampai dengan $39,316 \%$ sedangkan unsur $\mathrm{Sb}$ terletak nilai benar diantara konsentrasi $6,7 \mu \mathrm{g} / \mathrm{g}$ sampai dengan $7,3 \mu \mathrm{g} / \mathrm{g}$.

\section{DAFTAR PUSTAKA}

1. HOFMAN, J., LEICHT, R., and R., WINGENDER WORNER J. "Natural Radionuclide Concentrations in Materials Processed in the Chemical Industry and the Related Radiological Impact',. European Commission. Nuclear Safety and the Environment, Report EUR 19264, 2000.

2. IAEA., "Radiation Protection and NORM Residu Management in the Zircon and Circonia Industries", Safety Report Series, 51, Vienna, 2007.

3. RIGHI, S., VERITA, S., BRUZZI, L., and ALBERTAZZI, A., "Natural 
Radioactivity and Radon Specific Exhalation Rate of Zircon Sands", TA4Radiation Protection at Workplaces, Italian Ceramic Center Bologna, Bologna, 2005.

4. SUDJIOKO, D.W. dan TRYONO, "Peningkatan Kualitas Zirkonia Hasil Olah Pasir Zirkon", Jurnal Iptek Nuklir Ganendra, 11, 11-15, PTAPB-BATAN, Yogyakarta, 2008.

5. HAILU, T. H., CHAUBEYI, A. K., MAMO, D. A., and HIBSITE, A. Y., "Appliction of Intrumental Neutron Activation Analysis The Elemental Analysis of Various Rocks From Areas Around Debre Birhan City Ethiopia". www.arpapress.com/Volumes/ Vol12 Issue1/IJRRAS, 115-125,2012.

6. ANWAR H., "Pemahaman dan Penerapan ISO/IEC 17025: 2005. Persyaratan Umum Kompentensi Laboratorium Pengujian dan Laboratorium Kalibrasi, PT Gramedia Pustaka Utama, Jakarta, 2007.

7. BSN., Persyaratan Umum Kompetensi Laboratorium Pengujian Kalibrasi, ISO/IEC 17025, edisi kedua, Jakarta, 2005.

8. SUKIRNO dan SAMIN., "Estimasi Nilai Ketidakpastian Analisis Radionuklida Ra-226, Ra-228, Th-228 dan K-40 dalam Cuplikan Sedimen dengan Teknik Spektrometri Gamma", Jurnal Iptek Nuklir Ganendra, 14, 10-18, PTAPB-BATAN, Yogyakarta, 2010.

9. ERDTMANN, G. and SOYKA, W.,"The Gamma Ray of Radionuclides, Tables for Applied Gamma Ray Spectrometry", New York, 1979.

10. NATURAL RESOURCES CANADA, "Certificate of Analysis REE-1. Certified
Reference Material for Rare Earth Elements, Zirconium and Niobium", Ottawa, Canada, 2014.

11. MOREIRA, E.G., VASCONCELLEOS, B.A., and SAIKI, M., "Uncertainty Assessment in Intrumental Neutron Analysis of Biological Materials”, Jurnal of Radioanalytical and Nuclear Chemistry, 269, 377-382, 2006.

12. GREENBERG, R..R., "Publishing The Limits of NAA: Accuracy, Uncertainty and Detection Limits", Journal of Radioanalytical and Nuclear Chemistry, 278-2, 231-240, 2008.

13. SUKIRNO., dan TAFTAZANI A., "Penafsiran Ketidakpastian Analisis Fe, $\mathrm{Ca}, \mathrm{Zr}, \mathrm{Ba}$, $\mathrm{La}$, Ti dan $\mathrm{Ce}$ dalam Cuplikan Sedimen dengan Metode XRF," Jurnal Iptek Nuklir Ganendra, 13, 19-26, PTAPB-BATAN, Yogyakarta, 2010.

14. MURNIASI, S., ROSIDI, dan SUKIRNO, "Evaluasi Ketidakpastian Analisis Aktivasi Neutron pada Unsur Pendek dalam SRM NIST 1633B (Constituent Element in Coal Fly Ash)",, Prosiding PPI-PDIPTN, 22-27, PTAPBBATAN, Yogyakarta, 2013.

15. TULI, J.K., "Nuclear Wallet Cards" $8^{\text {th }}$ ed". National Nuclear Data Center. Brookhaven National Laboratory, New York, 2011.

16. FAISAL, W. dan NURANI, E., "Validasi Metode AANC untuk Pengujian Unsur Mn, Mg dan $\mathrm{Cr}$ pada Cuplikan Sedimen di Sungai Gajahwong", Jurnal Iptek Nuklir Ganendra, 13, 27-36, PTAPB-BATAN, Yogyakarta, 2010. 